\title{
An assessment of the Human-Elephant conflict in Sapahi and Kakadi Village of Kolhabi Municipality, Bara, Nepal
}

\author{
Akshay Chaudhary, Sachin Timilsina*, Subash Gautam and Prajwol Babu Subedi \\ Pokhara Campus, Institute of Forestry, Tribhuvan University, Pokhara 33700, Nepal \\ *E-mail: sachintimilsina66@gmail.com
}

\begin{abstract}
This study aims to assess the trend, extent, and impact of Human-Elephant conflict (HEC) in Sapahi and Kakadi villages of Bara district. Direct field observation, Household Survey (HHs), Focus Group Discussions (FGDs), and Key Informant Interview (KII) were carried out during November and December 2016 where 11 wards were selected purposively from two villages and 50 households from each village. Also, $12 \mathrm{KII}$ and one FGDs from each ward were performed. SPSS 20.0, and MS Excel 2016 were used to calculate mean, percentage, frequency count, and chisquare test was used to determine the variation in people's perception towards wild Elephant conservation. The total average damage of paddy per year per HHs was 834.1 $\mathrm{kg}$ followed by wheat $153.7 \mathrm{~kg}$, and mustard $2.12 \mathrm{~kg}$. The economic value of average annual crop damage per year per HHs accounted for NRs. 22669.70. Among total HHs, $84 \%$ of the respondents said that the trend of crop damage is increasing, $10 \%$ found no differences in crop damage, and remaining 6\% said decreasing. During the last 5 years, 7 people were injured, and 6 were killed. The lighting fire, beating drum, and making noise were the local techniques used by all the respondents to chase away elephant for the mitigation of HEC. The farmers also guard their fields at night time. $60 \%$ of the respondents are positive towards elephant conservation and remaining $40 \%$ seems no significance for conservation. The compensation scheme for crop damage should be properly implemented in the study area to minimize the HEC. A sustained conservation education program especially focusing on female, farmers, and nomads are recommended to conserve wild elephants, and their habitat.
\end{abstract}

Key words: Conflict, crop damage, mitigation, perception, wild elephant

DOI: https://doi.org/10.3126/on.v19.i1.41223

Manuscript details: Received: 11.05.2021 / Accepted: 14.10.2021

Citation: Chaudhary, A., S. Timilsina, S. Gautam and P.B. Subedi. 2021. An assessment of the Human-Elephant conflict in Sapahi and Kakadi Village of Kolhabi Municipality, Bara, Nepal. Our Nature 19(1): DOI: https://doi.org/10.3126/on.v19.i1.41223

Copyright: (C) Chaudhary, Timilsina, Gautam and Subedi 2021. Creative Commons Attribution - Non Commercial 4.0 International License.

\section{Introduction}

Nepal is a diverse, unique, and small Himalayan country that serves as a major habitat of the Asian Elephant (Elephas maximus) (Jnawali et al., 2011; Thapa and Dhakal, 2014). E. maximus is native to 13 Asian countries including Nepal and is incorporated in the International Union for Nature Conservation (IUCN) Red List of Threatened Species as "Endangered" (Choudhury et al., 2008; IUCN, 2018) and appendix I of the Convention on International Trade in Endangered Species of
Wild Fauna and Flora (CITES, 2017). National Parks and Wildlife Conservation (NPWC) Act 1973 has enlisted the E. maximus as a protected species (GoN, 1973) since the population has diminished by at least $50 \%$ over the past three generations (Yadav, 2005, 2007; Shrestha and Koirala, 2013; Yadav et al., 2013). Wild elephants thrive in four separate populations ranging over $10,982 \mathrm{~km}^{2}$ of forest habitat in the lowland Terai of Nepal and are estimated to having a population of 107-145 (DNPWC, 2008; Pradhan et al., 2011). Widespread loss of habitat, 


\section{Chaudhary, Timilsina, Gautam and Subedi / Our Nature | December 2021 | 19 (1): 27-36}

forage degradation, and demoted landscape connectivity leads to a significant drop in elephant populations relative to their historical size and overall range across Asia and Africa (Thouless et al., 2016; Calabrese et al., 2017). In Terai region of Nepal, after the eradication of malaria in 1950s, resettlement program, construction of Mahendra East-West highway, and other sub highways have destroyed a huge proportion of forest area (Yadav, 2007; Thapa and Dhakal, 2014). This directly affects the habitat and migratory routes of elephants (Pradhan et al., 2011). As a result of habitat shrinkage, elephants are pushed into closer association with people, resulting in more frequent and harsh conflict over space and resources with outcomes differing from cropraiding to reciprocal loss of life (White and Ward, 2010; Liu et al., 2017). Crop damage by wild Elephants is reported to be a widespread concern and has been a root matter of HumanElephant Conflict (HEC) (Shrestha, 2007). Due to the degraded forest, the wild elephant comes into direct interaction with local people while searching their food. In this way, they have been habituated towards food crops which are more palatable and nutritious than wild browse plants (Sukumar, 1990; Thapa and Dhakal, 2014). The forest encroachment, habitat loss and fragmentation made Elephant endangered. There are no elephant poaching issues in recent years but every year 2-3 elephants are being killed due to HEC (Shrestha and Shrestha, 2021). People face, injury, crop and property damage, and death too from wild elephants (Parker et al., 2007), and in the sense of retaliation, elephants are often executed. Therefore, HEC poses the most severe threat to elephant survival in heavily populated Asian countries. Various studies have documented problems of HEC, people's perception towards elephant conservation, and economic loss, but very few studies have explored the causes and mitigation measures of HEC. Also, every research program against HEC was conducted only in and around the Protected Areas (PAs). Therefore, this study is expected to assist in designing a practical plan to identify the causes of HEC and come up with possible strategies to depreciate the conflict outside the PAs. This study is performed to assess the status, trend, extent, and impact of HEC in Bara district of Nepal over the last five years. Also, to analyze people's perception towards HEC and mitigation measures adopted by locals that can aid conservation practitioners and ensures the longterm survival of elephants.

\section{Materials and methods}

\section{Study area}

The study area lies in the Bara district, Nepal. Two villages (Sapahi and Kakadi) of Kolhabi Municipality were selected for the study purpose. These two villages are located in the Southern low land of the Terai zone. These villages areas are more prone to wild elephant conflict than other areas. They damage the food and cash crops yearly, and human casualties also occur each year. Sapahi and Kakadi villages were inhibited by a population of about 2500, who reside in 500 households. The reserve mainly consists of tropical forest (about 92\%) dominated by Sal (Shorea robusta), and its associated species. The forest types can be distinguished into the mixed-deciduous riverine forest, mixdeciduous hardwood forest, $S$. robusta forest, and Khair (Acacia catechu) forest. Among the plant species, Satisal (Dalbergia latifolia) is becoming rare due to large extraction in the past. Imperata, Saccharum, Cymbopogon, Cynodon, and Desmostachya, etc. are the major grass species found in this area. Southern low lands are home to the endangered fauna, which are the indicators of low land ecology. Wild elephant, common leopard, jackal, wild boar, chital, etc. are the major fauna inhibiting in Bara districts of Nepal. 


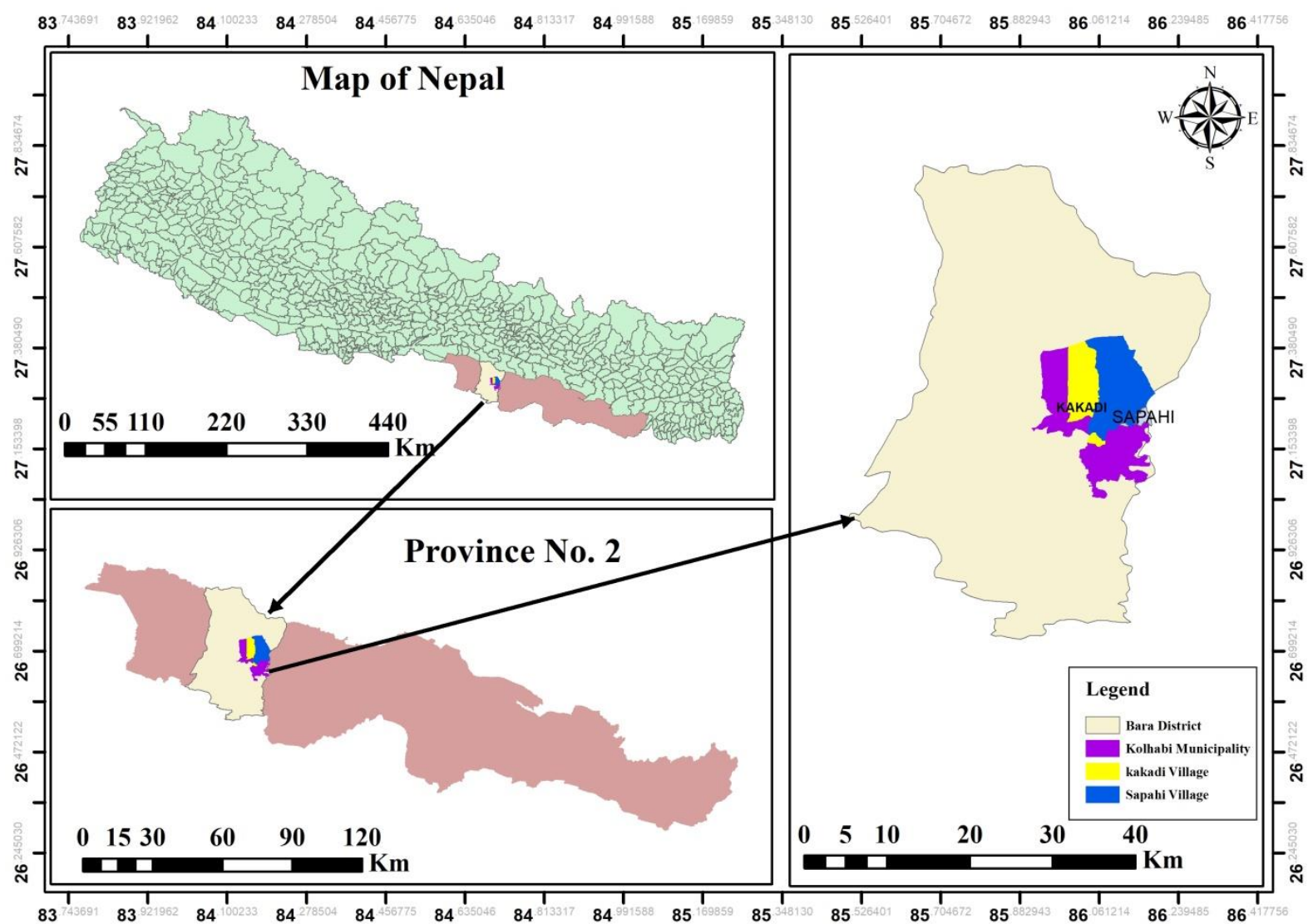

Figure 1. Map showing the Sapahi and Kakadi villages of Bara, Nepal.

\section{Data collection}

Primary data collection was performed by using the following tools:

Field visit and Reconnaissance Survey: A reconnaissance survey was carried out to know the general information of the field and further planning of the research before starting detailed field works. The location of some incident site with the help of victims or their representatives or eye witness was recorded with the help of the Global Positioning System (GPS). But the locations of the victim's household were not recorded unless the incident occurred at home.

Household Survey (HHs): HHs were conducted using the schedule. The sampling frame was based on an alphabetical listing of the household's head that was collected with the help of local people. A total of $100 \mathrm{HHs}$ were selected randomly $3 \mathrm{~km}$ near to forest area, i.e., 50 from Kakadi and 50 from Sapahi village. The sampling intensity was taken different due to varied in $3 \mathrm{Km}$ distance and population distribution of $\mathrm{HHs}$ from the forest.

Table 1. Sampling Intensity.

\begin{tabular}{lcccc}
\hline Selected village & Total HHs & Sampled HHs & Intensity & Remarks \\
\hline Sapahi & 208 & 50 & 24.04 & Homogenous \\
Kakadi & 290 & 50 & 17.24 & Homogenous \\
\hline Total HHs & $\mathbf{4 9 8}$ & $\mathbf{1 0 0}$ & $\mathbf{2 0 . 0 8}$ & \\
\hline
\end{tabular}

(Source: Field survey, 2016)

\section{Focus Group Discussions (FGDs)}

Checklists were used during FGDs. A total of 10 FGDs were carried out i.e. Six FGDs in Kakadi, and four in Sapahi village and one in two wards. A different group of people was selected such as male, and female farmers, both male and female mixed farmers, local political leaders, and real victim groups. This study helped to find out people strata, conflict variation, perception, and attitude towards Elephant conservation. 


\section{Key Informant Interview (KII)}

Checklists were used during the KII. 12 KII were carried out i.e. Six KII in Kakadi, Five KII in Sapahi village, and One from the District forest office (DFO), Bara. Mostly the old age people were taken as Key Informant in the village level to know the trend, extent, causes, and traditional methods used to control Elephant damage. This interview helped to cross-check the information provided during HHs.

Similarly, the secondary data were collected from various published and unpublished books, reports, journals, scientific articles, internet surfing, and other relevant literature using different databases like Research Gate, Google Scholar, and Scopus.

\section{Data analysis}

Data analysis consisted of both descriptive as well as inferential statistics. It was performed by using a standard computer-based SPSS-20, Microsoft Excel 2016, and Arc GIS 10.3 version was used to prepare the map of the study area.

\section{Results}

\section{Demography and extent of damage}

Demography: A total of 100 households were interviewed in the Sapahi (50) and Kakadi (50) village. Only those households were interviewed who were victims. The respondents interviewed were a mean age of 56. Most of the respondents were engaged in agriculture and animal husbandry while only a few percent were engaged in business and other employment activities. Among them $61 \%$ were male and $39 \%$ were others. The respondents were 18 years above.

Almost $80 \%$ of people living $3 \mathrm{Km}$ near the forest area were found suffering from crop damage by a wild elephant. Only $10 \%$ are safe from crop damage. It is because these two villages are adjacent to the forest boundary. During the study period, it was found that the female elephant with the baby damages the crop most.

\section{Types of crop damage}

100 households of two villages owned 14.96 hectares of land with average land of 0.149
Descriptive statistics including mean, percentage, frequency count was used to describe age, sex, education, and others values and inferential statistics including chi-square test was used to determine the variation in people's perception towards wild Elephant conservation. The findings of the study are graphically presented in charts, diagrams, and tables.

The economic loss of crop per year per household was determined by the following formulae.

The economic value of crops per year per HHs $=$ Average damage per year per $\mathrm{HHs}$ in $\mathrm{Kg} *$ Local market value of each crop per $\mathrm{kg}$

Average damage per year per $\mathrm{HHs}$ (in $\mathrm{Kg}$ ) = Total damage of crops of sampled HHs

Number of sampled HHs

Total damage of crops of sampled HHs= Sum of the total damage of crops each sampled HHs (Adopted by Ayadi, 2011)

hectares. In Sapahi, among the crop damage, $77.66 \%$ was paddy, $21.61 \%$ wheat, and $0.73 \%$ mustard. In the same way, in Kakadi paddy was damaged by $84.86 \%$, wheat $14.37 \%$, and mustard by $0.77 \%$. On average, $80.95 \%$ of the damaged crop was Paddy (Rice), $18.31 \%$ wheat, and only $0.75 \%$ was mustard. Table 2 and Table 3; show the crop damage in the two villages respectively.

\section{Major reasons behind conflict}

From the discussions carried out with the respondents, FGDs, and KII, the shrinkage of the forest area, and lack of food materials were the main reason for crop damages.

\section{Crop Damage Problem \\ Productions Status of Different Crops}

The production status of different crops grown in the two different villages is shown in Table 4. 
Chaudhary, Timilsina, Gautam and Subedi / Our Nature | December 2021 | 19 (1): 27-36

Trend of crop damage

Among 100 households surveyed, 84\% of the respondents said that the trend of crop damage is increasing. $10 \%$ of the respondents said that the trend of crop damage is the same as before, and the remaining $6 \%$ of the respondents said crop damage is in decreasing trend which is shown in Figure

Table 2. Crop damage in Sapahi and Kakadi.

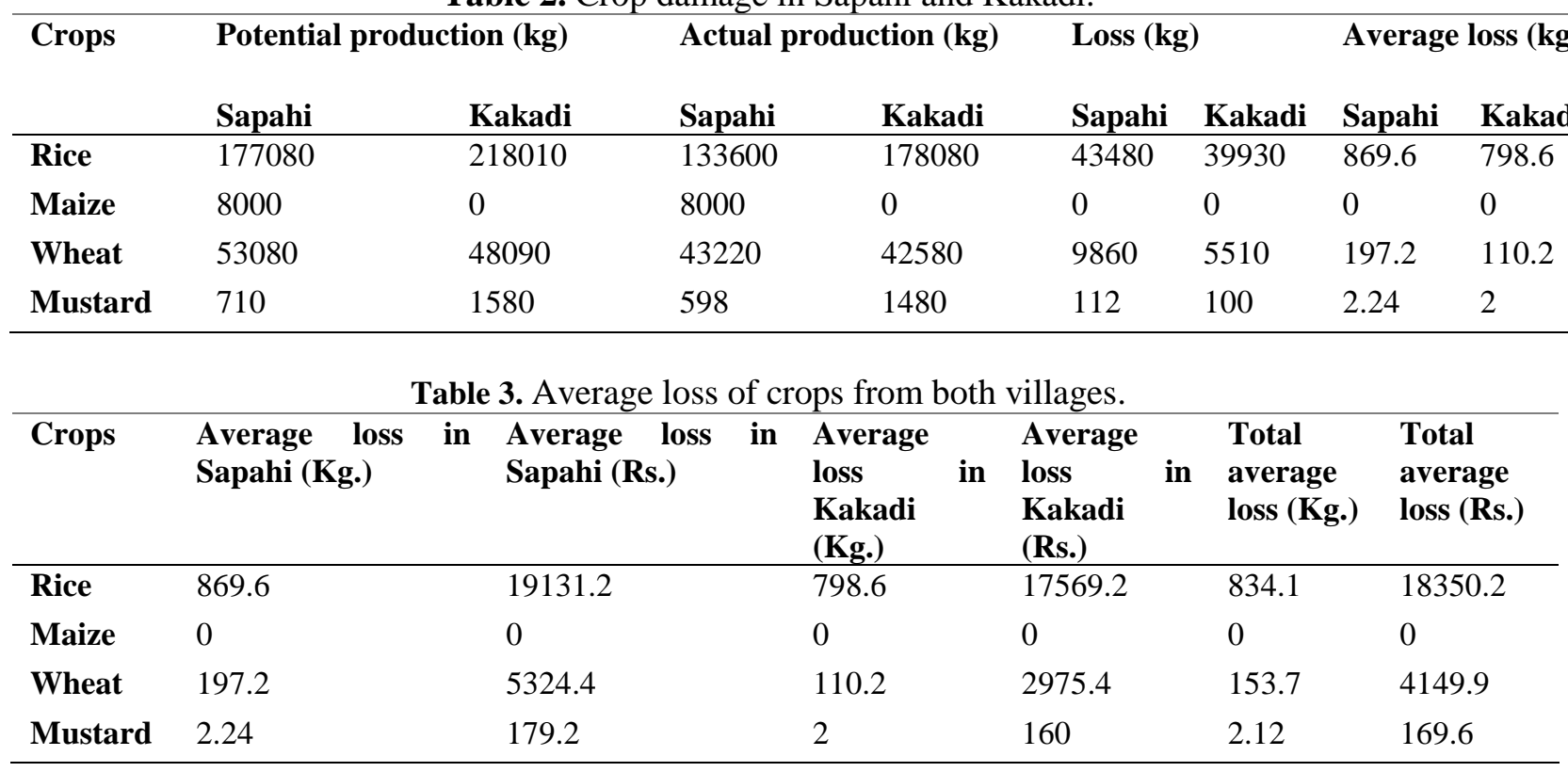

Table 4. Production in Sapahi and Kakadi.

\begin{tabular}{lllll}
\hline Crops & \multicolumn{2}{l}{ Potential production $(\mathbf{k g})$} & \multicolumn{2}{l}{ Actual production $(\mathbf{k g})$} \\
& Sapahi & Kakadi & Sapahi & Kakadi \\
\hline Rice & 177080 & 218010 & 133600 & 178080 \\
Maize & 8000 & 0 & 8000 & 0 \\
Wheat & 53080 & 48090 & 43220 & 42580 \\
Mustard & 710 & 1580 & 598 & 1480 \\
\hline
\end{tabular}




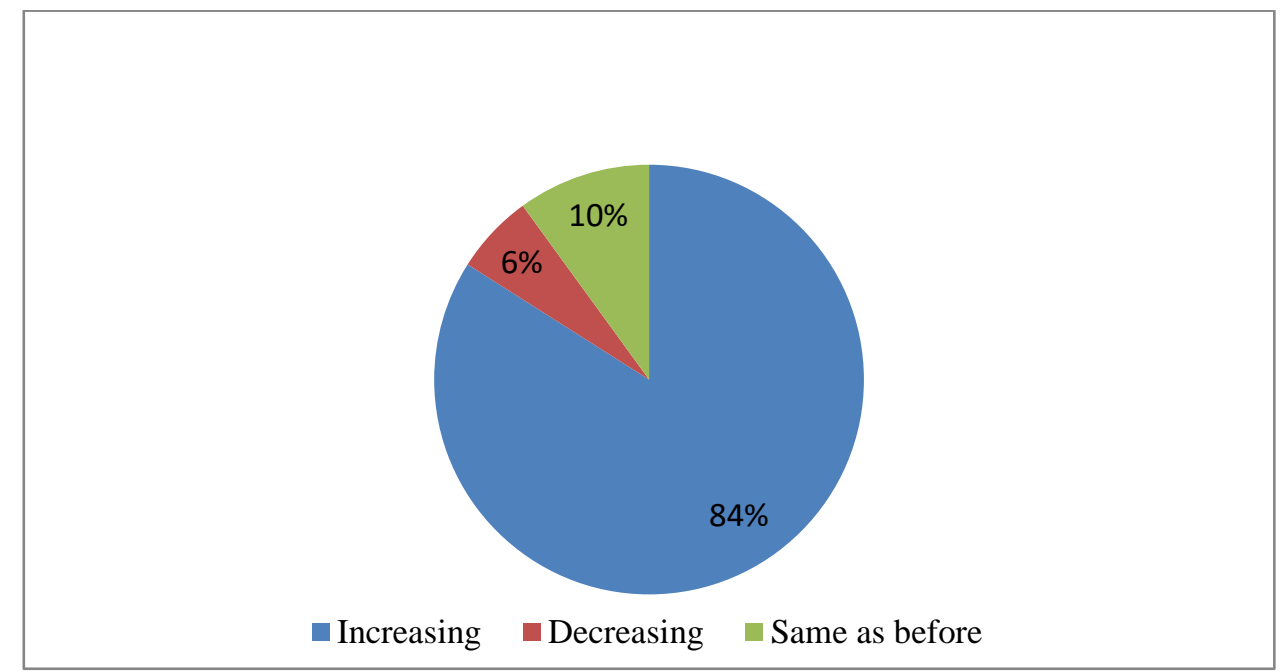

Figure 2. Diagram showing the trend of crop damages.

\section{Human casualties}

The numbers of respondents who encountered and not encountered the wild elephant, and are being injured or killed over the last five years in Sapahi and Kakadi was shown in Figure 3:

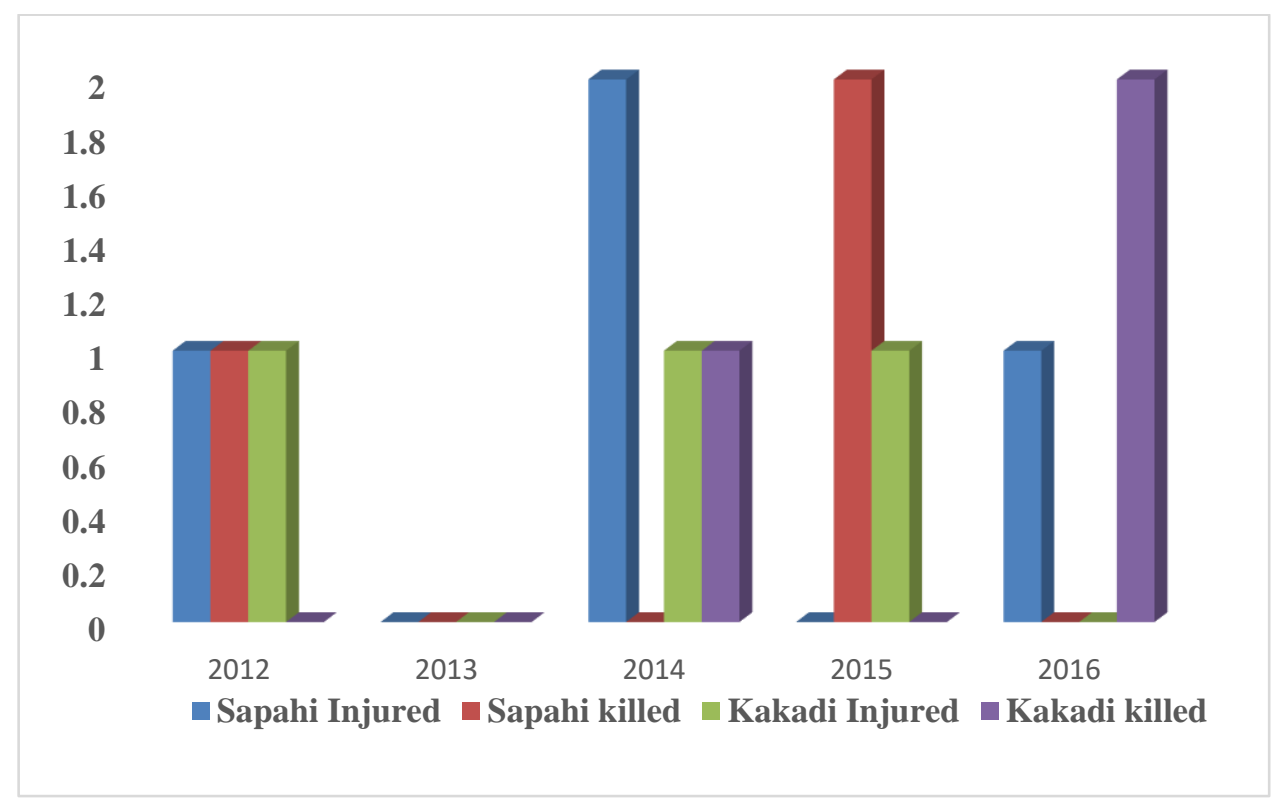

Figure 3. People killed and injured in Sapahi and Kakadi village.

\section{Mitigation Measure Adopted in the Study Area} No one of the respondents used only a single method to guard their field. All respondents used the lighting fire and making noise methods for chasing the wild elephant. A total of 52 respondents among 100 used the lightening fire, making noise as well as burning explosive methods. Besides using different methods, people also used night stay as mitigating measures by staying in tree houses to guard the field crops. 
Chaudhary, Timilsina, Gautam and Subedi / Our Nature | December 2021 | 19 (1): 27-36

The perception of local people towards wild elephant conservation is shown in Table 5 .

Table 5. Perceptions of local peoples towards wild elephant conservation.

\begin{tabular}{|c|c|c|c|c|c|c|}
\hline \multirow[t]{2}{*}{ Factor } & \multicolumn{6}{|c|}{ Attitudes towards the conservation of the Elephant } \\
\hline & & Yes & No & $\begin{array}{l}\text { Total } \\
\text { Respondent }\end{array}$ & P-value & Remarks \\
\hline \multirow[t]{2}{*}{ Sex } & Male & $40(65.57 \%)$ & $21(34.43 \%)$ & $61(100 \%)$ & & $*$ \\
\hline & Female & $20(51.28 \%)$ & $19(48.72 \%)$ & $39(100 \%)$ & 0.024 & \\
\hline \multirow[t]{2}{*}{ Education } & Literate & $46(75.41 \%)$ & $15(24.59 \%)$ & $61(100 \%)$ & & $*$ \\
\hline & Illiterate & $14(35.9 \%)$ & $25(64.9 \%)$ & $39(100 \%)$ & 0.028 & \\
\hline \multirow[t]{3}{*}{$\begin{array}{l}\text { Age } \\
\text { category }\end{array}$} & $\begin{array}{l}\text { Young (20- } \\
40)\end{array}$ & $30(63.83 \%)$ & $17(36.17 \%)$ & $47(100 \%)$ & & \\
\hline & Adult(41-60) & $29(55.77 \%)$ & $23(44.23 \%)$ & $52(100 \%)$ & 0.155 & \\
\hline & Old(60+) & $1(100 \%)$ & $0(0 \%)$ & $1(100 \%)$ & & \\
\hline
\end{tabular}

Note- * Stands for a significant effect on attitude towards the wild elephant.

Despite crop damage, people are positive $(P<0.05)$ towards wild elephant conservation. Male and literate respondents foster a somewhat positive view than female and illiterate respondents which may be due to the lack of awareness about a wild elephant and their

\section{Discussion}

Our study showed that the scale of HEC varies according to the different types of incidents (crop damage, human casualties), which are similar to the study performed by Koirala et al. (2021) in the villages distributed throughout the northern and southern buffer zones of Chitwan National Park (CNP) and Parsa National Park (PNP). Similar to the others research, the HEC is higher in this study site with notable impacts on agriculture and livelihood (Yadav, 2002; Shrestha, 2007). The economic loss due to crop damages is the primary impact of HEC (Davies et al., 2011). A crop raiding was the major problem due to the conflict. Since several crops provide proteins for the elephant herd, it is believed to be the primary cause of elephant movement towards this site which is similar to the study performed importance among females and illiterate. Among the 100 respondents, $60 \%$ of the respondent said it is necessary to conserve wild elephants, and the remaining $40 \%$ said it is not necessary to conserve wild elephants.

by Dhakal and Thapa (2019) in Bahundangi, Nepal. Rice was the major crop damaged by an elephant in our two study sites. A similar result was found in the research carried by Koirala et al. (2021) where rice was the most frequently raided crop. A study performed by Sukumar (2003) in the moist tropics of Asia also concluded rice as the most preferred crop of elephants followed by maize, wheat, and millets. Our study shows more conflict near forest boundaries. A similar trend has been reported in Nepal by the study performed by Sukumar (1990) and by Pant and Hockings (2013). Our study suggests more conflicts near the forest area than distant villages. The study by DiFonzo (2007) and Lahkar et al. (2007) also found a similar trend of conflict in their study in fringe villages of Kaziranga National Park, UK, and Manas National Park 
within Chirang-Ripu Elephant Reserve, Assam respectively. The conflict is highest close to protected areas (DiFonzo, 2007), and the number of incidents decreases with the increasing distance of villages from the forest boundary (Lahkar et al., 2007). The perceptions toward elephant conservation were varied among men, literate, female, and illiterate people. A study carried out by Pant et al. (2016) reveals variation in attitudes towards elephant conservation in the vicinity of CNP. Eight out of Nine respondents who lost the family members have negative perceptions of an elephant which is a contrast to our study where $60 \%$ of total respondents in our study thought elephants need to be conserved. There exists a complex community relationship with elephants and based on the Hindu religion, elephants are revered as God Ganesh (Dhakal and Thapa, 2019). The peoples in these two villages also promote their interest in elephant conservation due to religious, ethical values and as a national property. The management strategies must be scientifically sound and technically feasible to reduce HEC (Fernando et al., 2009). Lightening

\section{Conclusion}

The study reveals that Human-Elephant Conflicts are increasing in Kakadi and Sapahi villages of Bara district. The conflicts are more prominent near the forest boundary than distant settlements. Rice and wheat are the most damaged crops. There is injury or death of people near the forest area where conflict is higher. Despite increasing trend of Human-Elephant Conflict, majority of people wants to conserve the wild elephant which indicates people are positive $(p<0.05)$ towards

\section{Acknowledgments}

The authors would like to acknowledge Mrs. Nirjala Raut (Assistant professor), IOF, Pokhara for guiding us throughout our study period. The credit would also go to Prabin Bhusal (Assistant professor), IOF, Pokhara for his valuable guidance and constructive suggestions in the data analysis and summarization process. We would like to thank ACO Mr. Robin Chaudhary, AFO Mr. Ram Balak Patel, and AFO Mr. Bal Kumar Nepali as a source of inspiration and encouragement to make our research successful. of fire, making noise, and burning explosives are the methods to reduce HEC. A study performed by Shrestha (2007) also concluded that creating loud noises such as using firecrackers or drums during the night time deter elephant's from crossing the border along the eastern corridor connected to India. The residents also tried to minimize the damage caused by elephants by creating loud noises, or by using fire or fog lights (Choudhury, 2004; Shrestha, 2007). Our findings suggest that public awareness and compensation are major tools to minimize conflict between people and elephants in Nepal. Less information on elephant behavior causes more human casualties as people come near elephants to prevent their crop damage which is similar to the findings of Pant et al. (2016). Awarenessraising activities must be carried out to avoid interactions with elephants and thus minimize conflict for people living in conflict zones, and garner public support for elephant conservation. The mechanism of fencing should be carried out based on a community-based ownership model along with a funding mechanism for maintenance.

Asian wild elephant even though they faced a large amount of crop damage and human casualty yearly. The reasons behind expressing interest in the conservation of wild elephants are religious/ethical values and considering elephants as a natural wealth as well as national property. This study confirms the Human-Elephant Conflict in this study area and could be important baseline information for zoologists, foresters, and wildlife researchers, different governmental and nongovernmental institutions for conflict mitigation.

We would also like to express our gratitude to the people of Sapahi and Kakadi village, who were the respondents for the primary data collection of this research. We are grateful to farmers, local leaders, local youths, DFO Bara staffs, and local teachers who shared with us the information needed for our research.

\section{References}

Ayadi, D.P. 2011. Human-Wildlife conflict in Buffer Zone area. A case study of Banke National Park of Nepal. Environment 
Science, College of Applied Sciences, T.U. (M.Sc. Thesis).

Calabrese, A., J.M. Calabrese, M. Songer, M. Wegmann, S, Hedges, R. Rose and P. Leimgruber 2017. Conservation status of Asian elephants: the influence of habitat and governance. Biodiversity and Conservation 26(9): 2067-2081. https://doi.org/10.1007/s10531-017-13455

Choudhury, A. 2004. Human-elephant conflicts in Northeast India. Human dimensions of wildlife 9(4): 261-270. https://doi.org/10.1080/10871200490505 693

Choudhury, A., D.K. Lahiri Choudhury, A. Desai, J.W. Duckworth, P.S. Easa, A.J.T. Johnsingh, P. Fernando, S. Hedges, M. Gunawardena, F. Kurt, U. Karanth, A, Lister, V. Menon, H. Riddle, A. Rübel and E. Wikramanayake 2008. Elephas maximus [WWW Document]. IUCN Red List Threat. Species. https://doi.org/10.2305/IUCN.UK.2008.R LTS.T7140A12828813.en

CITES. 2017. Appendices I, II and III, Convention on international trade in endangered species of wild fauna and flora.

Davies, T.E., S. Wilson, N. Hazarika, J. Chakrabarty, D. Das, D.J. Hodgson and A. Zimmermann 2011. Effectiveness of intervention methods against crop-raiding elephants. Conservation Letters 4(5): 346-354. https://doi.org/10.1111/j.1755263X.2011.00182.x

Dhakal, B. and B. Thapa 2019. Residents' perceptions of Human-Elephant Conflict: case study in Bahundangi, Nepal. Environment, development and sustainability 21(1): 461-481. DOI 10.1007/s10668-017-0047-1

Di Fonzo, M.M. 2007. Determining correlates of Human-Elephant Conflict reports within fringe villages of Kaziranga National Park, Assam. University of London and the Diploma of Imperial College (M.Sc. Thesis).
DNPWC. 2008. The Elephant Conservation Action Plan of Nepal. DNPWC, Kathmandu, Nepal.

Fernando, P., H.K. Janaka, S.K. Ekanayaka, H.G. Nishantha and J. Pastorini 2009. A simple method for assessing elephant body condition. Gajah 31: 29-31.

GoN. 1973. National parks and wildlife conservation act. Nepal: Government of Nepal, Nepal Law Commission.

IUCN. 2018. The IUCN redlist of threatened species. Retrieved from http://www. iucnredlist.org/initiatives/mammals.

Jnawali, S.R., H.S. Baral, S. Lee, K.P. Acharya, G.P. Upadhyay, M. Pandey, R. Shrestha, D. Joshi, B.R. Lamichhane, J. Griffiths, A. Khatiwada and R. Amin (Compilers). 2011. The Status of Nepal's Mammals : The National Red List Series.

Koirala, R.K., J.I. Weihong, Y.P. Timilsina and D. Raubenheimer 2021. Patterns, perceptions, and spatial distribution of Human-Elephant (Elephas maximus) incidents in Nepal. Journal of Threatened Taxa 13(6): 18441-18452. DOI: 10.11609/jott.2021.13.6.18411-18678

Lahkar, B.P., J.P. Das, N.K. Nath, S. Dey, N. Brahma and P.K. Sarma 2007. A study of habitat utilization patterns of Asian elephant Elephas maximus and current status of human elephant conflict in Manas National Park within ChirangRipu Elephant Reserve, Assam. Report, Aaranyak, Guwahati, Assam, India.

Liu, P., H. Wen, F.K. Harich, C. He, L. Wang, X. Guo, J. Zhao, A. Luo, H. Yang, X. Sun, Y. Yu, S. Zheng, J. Guo, L. Li and L. Zhang. 2017. Conflict between conservation and development: cash forest encroachment in Asian elephant distributions. Scientific Reports 7(1): 110. doi: 10.1038/s41598-017-06751-6

Pant, G. and M. Hockings 2013. Understanding the nature and extent of Human-Elephant conflict in central Nepal. University of Queensland, 38pp. (Masters research report).

Pant, G., M. Dhakal, N.M.B. Pradhan, F. Leverington and M. Hockings. 2016. Nature and extent of Human-Elephant 
Elephas maximus conflict in central Nepal. Oryx $\quad$ 50(4): 724-731. https://doi.org/10.1017/S0030605315000 381

Parker, G.E., F.V. Osborn and R.E. Hoarse. 2007. Human-elephant conflict mitigation: a training course for community-based approaches in Africa (Participant's Manual).

Pradhan, N.M., A.C. Williams and M. Dhakal. 2011. Current status of Asian elephants in Nepal. Gajah 35: 87-92.

Raman Sukumar. 2003. The living elephants: evolutionary ecology, behaviour, and conservation. Oxford University Press.

Shrestha, R. 2007. A case study on humanwildlife conflict in Nepal. Kathmandu: Elephant Family.

Shrestha, R. and D.P. Koirala. 2013. ElephantHuman conflict in Bahundangi region, Jhapa District, Nepal. Journal of Natural History $\quad$ Museum 27: 59-65. https://doi.org/10.3126/jnhm.v27i0.14153

Shrestha, S. and J. Shrestha. 2021. Asian elephants and their status in Nepal: A review. Journal of Agriculture and Natural Resources 4(2): 227-237. https://doi.org/10.3126/janr.v4i2.33828

Sukumar, R. 1990. Ecology of the Asian elephant in southern India. II. Feeding habits and crop raiding patterns. Journal of Tropical Ecology 6(1): 33-53. https://doi.org/10.1017/S0266467400004 004
Thapa, B. and B. Dhakal. 2014. Human-Elephant Conflict: household impact assessment in Bahundangi VDC, Nepal. University of Florida. (A report).

Thouless, C., H.T. Dublin, J. Blanc, D.P. Skinner, T.E. Daniel, R. Taylor, F. Maisels, H. Frederick and P. Bouché. 2016. African elephant status report 2016. Occasional paper series of the IUCN Species Survival Commission, 60.

White, P.C. and A.I. Ward. 2010. Interdisciplinary approaches for the management of existing and emerging Human-Wildlife Conflicts. Wildlife Research 37(8): $\quad$ 623-629. https://doi.org/10.1071/WR1019

Yadav, B. 2002. Elephant (Elephas maximus) People Interface in East Nepal. Agriculture University of Norway, Norway. (M.Sc. Thesis).

Yadav, B.R. 2005. Asian wild elephant (Elephas maximus) in eastern Nepal. The Journal of Forestry 12(3): 68-81.

Yadav, B.R. 2007. Human-Elephant relationships and conflicts in eastern Nepal. The Initiation 1: 93-99. https://doi.org/10.3126/init.v1i0.2689

Yadav, B.R., I.C. Dutta, M.K. Chilese, C. Williums and B.K. Sharma. 2013. Habitat utilization by Asiatic Wild Elephant (Elephas maximus) in Parsa Wildlife Reserve, Nepal. Ecoprint: An International Journal of Ecology 20: 4152.https://doi.org/10.3126/eco.v20i0.11440 